Brit. J. industr. Med., 1961, 18, 143.

\title{
OBSERVATIONS ON THE PATHOGENESIS OF SILICOSIS BY MEANS OF THE DIFFUSION CHAMBER TECHNIQUE
}

\author{
BY \\ A. G. HEPPLESTON, ${ }^{*}$ K. A. AHLQUiST, and D. WILliAMS \\ From the Department of Pathology, University of Wales, Cardiff
}

(RECEIVED FOR PUBLICATION SEPTEMBER 7, 1960)

\begin{abstract}
An attempt has been made to determine whether the diffusion chamber technique can be used to decide the validity of the silica solubility theory of the pathogenesis of silicosis. Small chambers were constructed from membranes of a pore size which allowed free passage of colloidal silicic acid and tissue fluids but which prevented the entry of host cells and the exit of the larger silica particles. Significant fibrosis failed to develop around chambers containing five different forms of silicon dioxide when inserted subcutaneously and intraperitoneally in rats and rabbits. All five forms of silica were actively fibrogenic when brought into direct contact with peritoneal tissues. However, in vitro experiments suggest that colloidal silicic acid, the form which may be involved in silicotic fibrosis, does not escape from the chambers. Thus the biological results obtained by this technique do not necessarily invalidate the silica solubility theory of the pathogenesis of silicosis.
\end{abstract}

The proximate mechanism by which silicon dioxide induces fibrillogenesis is still undecided. The silica solubility theory of the pathogenesis of silicosis, introduced by Gye and Purdy $(1922 ; 1924)$ and Gye and Kettle (1922), stimulated numerous investigations, some of which cast doubt on the validity of the theory. Gardner (1934) noted that certain silicates were not so active as quartz although they were more soluble. Later Gardner (1937) summarized the evidence for and against the solubility theory, whilst King, Zaidi, and Nagelschmidt (1956) drew attention to the difficulty of reconciling certain experimental findings with it. Holt and Osborne (1953) and Holt and Went (1960) attempted to modify the solubility theory, whilst Jäger (1954) and Seifert (1954) suggested that silicotic fibrosis may depend on surface properties of silica particles. Marks and Nagelschmidt (1959) considered that cellular injury, induced by ingested silica, was an important step in the fibrotic response.

Several attempts have been made to determine the role of soluble silica in silicosis by the in vivo use of capsules or chambers made from porous membranes, intended to separate enclosed silica particles from the cellular tissues outside but to permit the exit

*Present address: Department of Pathology, University of Durham, Royal Victoria Infirmary, Newcastle upon Tyne. from the chamber of soluble silica and the entry of tissue fluids. We have applied this technique to an extended range of dusts and have studied the rate at which soluble silica, liberated from particles, diffuses through the membranes under various conditions. Our results confirm that the fibrotic reaction around dust chambers is no greater than around control chambers, but it seems that the amount of soluble silica liberated from the chambers may be too small to be biologically active.

\section{Diffusion Chamber Studies Methods}

The technique adopted was a slight modification of that devised by Algire, Weaver, and Prehn (1954).

Dusts were enclosed in chambers constructed from thin perspex rings, to each side of which a Membranfilter (type 10, pore size $<0 \cdot 1 \mu$ ) was sealed with thin perspex cement. Control chambers were constructed similarly but contained no dust. Chambers were placed in water and sterilized by heating to $70^{\circ} \mathrm{C}$. for one and a half hours on three occasions or by steaming for one hour, after which dust and control chambers contained water. Immediately after sterilization 50 chambers containing various dusts and 25 control chambers were inserted subcutaneously into both flanks and into the peritoneal cavity of 20 rats and five rabbits. The dusts included 
(a) four physical forms of silicon dioxide, namely tridymite, cristobalite, quartz, and vitreous silica (a total of 40 chambers with $50 \mathrm{mg}$. in each), (b) Aerosil, a dried silica gel (five chambers of $10 \mathrm{mg}$. each), and (c) anthracite (five chambers of $25 \mathrm{mg}$. each). The siliceous dusts had a Stokes' diameter of 0.5-2 $\mu$; Aerosil particles were $200-300 \AA$ (Nagelschmidt, personal communication) and may thus be regarded as falling within the size range of colloidal particles (Philbrick, Holmyard, and Palmer, 1949); the anthracite was less than $5 \mu$ in particle size. Animals were killed at intervals of one to 12 months. The observations were mostly histological, but some chambers were tested for permeability or for loss of silica dust.

\section{Results}

Control chambers in the subcutaneous tissues were often lightly adherent whereas in the peritoneum more were free from adhesions. Histologically controls from rats and rabbits showed a zone of compact fibrosis (60-120 $\mu$ thick), which lay externally to the membrane (60 $\mu$ thick) and which became more hyaline with the passage of time. This fibrous layer was easily detached from the membrane, to which a single layer of rather flattened cells tended to adhere. The reaction around dust chambers was similar to or occasionally less than that shown by controls and was uninfluenced by the type of dust employed, whether siliceous (including Aerosil) or carbonaceous. Previous experiments (A.G.H.) confirmed that all these siliceous dusts (but not the carbonaceous) were fibrogenic when brought into direct contact with the peritoneum of rats. Occasionally siliceous dust chambers ruptured in vivo unintentionally and then an intense fibrotic reaction occurred around them.

Several dust chambers (tridymite, quartz, and Aerosil), which had been used in the animal experiments for a year, were subsequently tested to see how easily carboxyhaemoglobin ( $\mathrm{COHb}$ ) escaped from within, through the dust mass and membrane, to the outside. The membrane sealing one side of the chamber was carefully opened and the lower membrane supported in water held in a Petri dish. A little $\mathrm{COHb}$ solution was placed on the surface of the dust mass and the dish covered. In no case did $\mathrm{COHb}$ escape through the lower membrane in 24 hours.

The dust (quartz and cristobalite) was removed from two chambers taken out of rats after one year. Repeated chloroform extraction dissolved the perspex and the dust-free membranes were discarded. The dust was then heated to $600^{\circ} \mathrm{C}$. for 12 hours and weighed. Silica loss averaged $6 \mathrm{mg}$., i.e. $12 \%$ of the original weight. Since control experiments with quartz dust chambers not placed in animals showed an experimental error of approximately
$2 \%$, about $10 \%$ of the dust was lost in vivo, a figure which agrees with that obtained by Pernis, Clerici, and Ghezzi (1958) and by Curran and Rowsell (1958).

\section{Tests of Membrane Permeability}

Perspex tubes, of the same diameter as the diffusion chamber rings, were sealed at one end with Membranfilter type 10 membranes and used for two sets of experiments.

1. The rate at which soluble silica, released from dust suspensions in the tubes, escaped through the membranes.

One ml. of an aqueous suspension of quartz, tridymite or Aerosil (500 and $1,000 \mathrm{mg} . / 100 \mathrm{ml}$.) was placed in a tube, the sealed end of which was suspended in $5 \mathrm{ml}$. water in a small waxed beaker. The apparatus was agitated continuously for one to two days and the concentrations of molybdate reactive (MR) and total silica estimated in the surrounding water by the methods of King, Stacy, Holt, Yates, Deidre, and Pickles (1955) and Paterson and Wheatley (1955). MR silica includes the monomeric and oligomeric forms of silicic acid, whilst the difference between the total and the MR silica gives the concentration of polymerized (colloidal) silicic acid. Permeability of membranes was controlled by using $1 \mathrm{ml}$. of standard silica solution $(10 \mathrm{mg} . / 100 \mathrm{ml}$.) prepared from sodium silicofluoride. All estimations were performed in duplicate on several occasions and the water used was distilled and silica-free.

Little MR silica $(0.1 \mathrm{mg} . / 100 \mathrm{ml}$. or less) escaped through membranes from quartz or tridymite suspensions of either concentration in one to two days; total and MR silica concentrations did not differ significantly, i.e. no colloidal silica was detected. In the case of Aerosil suspension $(500 \mathrm{mg} . / 100 \mathrm{ml}$.) the MR silica concentration outside the tube was $0.5-1.0 \mathrm{mg} . / 100 \mathrm{ml}$. and the total silica concentration was almost identical. Control experiments showed that MR silica solution readily diffused through the membranes and in one day achieved an average concentration of $1.3 \mathrm{mg} . / 100 \mathrm{ml}$. outside the tubes, while the internal concentration fell from 10 to an average of $1.8 \mathrm{mg} . / 100 \mathrm{ml}$.

In an attempt to approach in vivo conditions other experiments tested the escape of soluble silica from rabbit serum suspensions of dust $(1,000 \mathrm{mg} . / 100 \mathrm{ml}$.) into rabbit serum. All experimental estimations were read against normal rabbit serum as control and the results represent the increase of dissolved silica over the normal of approximately $0.25 \mathrm{mg} . / 100 \mathrm{ml}$. serum. The external MR silica concentration was again $<0.1 \mathrm{mg}$. $100 \mathrm{ml}$. from tridymite suspensions and from Aerosil $2 \mathrm{mg} . / 100 \mathrm{ml}$., whilst from standard silica solution in serum (10 mg./100 ml.) the external MR silica was $<0.5 \mathrm{mg} . / 100 \mathrm{ml}$. MR and total silica concentrations did not differ in any particular experiment.

2. The ability of a protein molecule to penetrate a compact mass of dust and a supporting membrane of the same porosity as that used in vivo was visualized by means of $\mathrm{COHb}$.

The same amounts of quartz, tridymite, and Aerosil 
TABLE

\begin{tabular}{|c|c|c|c|c|c|c|c|}
\hline \multirow[b]{2}{*}{ Experiment } & \multicolumn{3}{|c|}{ Medium } & \multicolumn{4}{|c|}{ Time for COHb Penetration (hrs) } \\
\hline & Inside Tube & $\begin{array}{l}1 \\
1 \\
1\end{array}$ & Outside Tube & $\begin{array}{c}\text { Control } \\
\text { (Dissolved } \\
\text { Silica) }\end{array}$ & Tridymite & Quartz & Aerosil \\
\hline $\begin{array}{l}\text { (a) } \\
\text { (b) } \\
\text { (c) } \\
\text { (d) } \\
\text { (e) } \\
\text { (f)* }\end{array}$ & $\begin{array}{c}\text { Water } \\
\text { Water } \\
\text { Water } \\
1 \text { in } 4 \text { serum } \\
\text { Undiluted serum } \\
\text { Water }\end{array}$ & ! & $\begin{array}{c}\text { Water } \\
1 \text { in } 4 \text { serum } \\
\text { Undiluted serum } \\
1 \text { in } 4 \text { serum } \\
\text { Undiluted serum } \\
\text { Water }\end{array}$ & $\begin{array}{r}1 \\
1 \\
3 \\
1 \\
24 \\
1\end{array}$ & $\begin{array}{r}3 \\
5 \\
24 \\
8 \\
32 \\
5\end{array}$ & $\begin{array}{r}3 \\
5 \\
24 \\
8 \\
32 \\
5\end{array}$ & $\begin{array}{r}27 \\
24 \\
96 \\
8 \\
48 \\
1\end{array}$ \\
\hline
\end{tabular}

*Penetration of $\mathrm{COHb}$ from without into the tube.

as were used in the animal experiments were weighed into tubes, which were held vertically in a rack with their membrane-sealed ends enclosed by small glass cups. A fourth tube was set up alongside for use as a control. Several procedures were adopted. (a) Distilled water was added to the dust tubes $(1 \mathrm{ml}$.) and to the cups so that the membranes were well covered. After the dusts had settled for six days, $1 \mathrm{ml}$. silica solution (see above) was placed in the control tube and its cup filled with water. A similar volume of $\mathrm{COHb}$ solution was added to each tube without disturbing the dust and the rate at which $\mathrm{COHb}$ diffused into the cups was observed. (b) Because the in vivo capsules were surrounded and permeated by protein-containing fluid, an attempt was made to study the influence of serum on diffusion of COHb. Water was added to the tubes and cups as in (a) above. Two days were allowed for the dusts to settle and the content of the cups changed to a 1 in 4 dilution of rabbit serum in water; $1 \mathrm{ml}$. silica solution was placed in the control tube and its cup filled with 1 in 4 serum. To all four tubes $\mathrm{COHb}$ was then added. (c) This experiment resembled (b) except that undiluted rabbit serum was used. (d) The only variation from (b) lay in the replacement of water by 1 in 4 rabbit serum inside and outside the dust tubes from the start. (e) This procedure differed from (d) in the use of undiluted rabbit serum, with which the control silica solution was diluted in equal parts. (f) The time taken by $\mathrm{COHb}$ to enter tubes containing compact masses of dust and control tubes from without in aqueous media was also observed.

The results (Table) showed that the much smaller Aerosil particles delayed the escape of $\mathrm{COHb}$ in aqueous media, presumably because they were in closer apposition than tridymite and quartz particles. Having percolated through the dust down to the membrane, $\mathrm{COHb}$ soon appeared in the surrounding fluid. Obstruction of membrane pores by dust particles thus appears unlikely. Serum ( 1 in 4$)$ around the tubes made no difference, but when placed in the tubes as well penetration through Aerosil was facilitated, apparently due to the formation of a less compact mass than in water. The appearance of $\mathrm{COHb}$ from aqueous suspensions into undiluted serum outside the tubes was considerably delayed. The same result obtained with undiluted serum in and around the tubes in the cases of tridymite and quartz, but in the control COHb was also held back; failure of Aerosil to compact in serum probably explained the quicker penetration by $\mathrm{COHb}$ as compared with aqueous suspensions diffusing into undiluted serum. Entry of $\mathrm{COHb}$ into the tubes from outside was delayed by tridymite and quartz in water but not by Aerosil, possibly because smaller particles are more easily lifted from the membrane and separated than larger, heavier ones.

\section{Discussion}

The first attempt to test the solubility theory of the pathogenesis of silicosis by the use of semipermeable capsules appears to be that of Kettle (1926), who implanted collodion sacs containing insoluble silicon dioxide subcutaneously in rabbits. The inflammatory reaction which developed around the sacs was similar to that evoked by silica in direct contact with the tissues. Banting (1936), on the other hand, failed to demonstrate silicotic fibrosis around cellophane sacs containing fine quartz dust after insertion into the peritoneal cavity. The pore size of collodion membranes is, however, influenced by the method of preparation, about which Kettle and Banting gave no details, and these early experiments cannot therefore be properly interpreted. The development of dry cellulose membranes with a known pore size greatly improved the reliability of experiments with diffusion chambers (Algire et al., 1954). Pernis et al. (1958) used quartz in chambers with a pore size of $0.3-0.5 \mu$ and found that no reaction of silicotic type developed around or inside the chambers after seven months in the subcutaneous tissues of rats. By the same technique and with membranes of $<0.1 \mu$ pore size, Curran and Rowsell (1958) were unable to demonstrate any difference in the reaction around chambers containing quartz or tridymite and those containing no dust or a non-fibrogenic dust when inserted subcutaneously or intraperitoneally in mice and guinea pigs. The evidence from both these investigations was considered to be opposed to the idea that silicotic fibrosis was mediated by solution of silica particles. The biological findings in the present experiments, using membranes of a pore size $<0.1 \mu$ and large amounts of dust, confirmed previous observations and further showed that the 
physical form of free silica particles had no bearing on the fibrotic response. It must be noted that silica in the form of Aerosil, with a particle size smaller than the pores of the membranes, failed to induce fibrosis.

To produce fibrous tissue a minimum local concentration of quartz particles is required (Schepers, 1958). In cultures of fibrogenic cells from embryonic chicken lung Chvapil and Holečková (1959) observed a pronounced stimulation of collagen formation by silicic acid, but its concentration was critical. Above a particular level of silicic acid collagen production was inhibited, whereas a lower concentration of acid was without effect. Similarly, a low concentration of quartz particles in the culture medium proved ineffective and a high concentration inhibitory to collagen formation. Chvapil and Holečková concluded that silicic acid in appropriate strength stimulated enzymatic activity in cells which participate in collagen synthesis. Knake, Peter, and MüllerRuchholtz (1959) noted that weak (i.e. monomeric or oligomeric) silicic acid had no effect on cultures of rabbit and guinea pig lung and spleen. Below a critical concentration silicic acid exists as low polymers or monomer, whilst above this level the acid consists of higher polymers (Scheel, Fleisher, and Klemperer, 1953; James and Marks, 1956). It may be argued, therefore, that only polymerized silicic acid is concerned in fibrosis, just as toxicity studies incriminate the polymerized form (James and Marks, 1956; Glömme, Holmquist, and Swensson, 1958). If few silica particles exist free in the tissues, little silicic acid will be liberated, its concentration in the tissue fluids will be low, and it will be highly dissociated. On this view fibrosis would not be expected. Previous and present results indicate that a small proportion of silica is in fact lost from diffusion chambers in vivo, but this loss occurs over a considerable period of time. It seems likely that, from a large mass of silica enclosed in a diffusion chamber, soluble silica will be released mainly by particles close to the membranes and that only a concentration too low to be fibrogenic may escape into the tissues. The failure of highly polymerized silica, in the form of Aerosil, to cause fibrosis around chambers may also be due to the slow rate at which the colloidal particles escape through the membranes and the consequent rapid dilution in tissue fluids to produce low polymers.

The tests of membrane permeability may be interpreted as supporting this view. MR silica, released from dusts kept in concentrated suspension, escaped through membranes in low concentration and serum did not influence significantly its rate of release, although control experiments with dissolved silica suggested that serum might reduce the rate at which it penetrated the membranes. Scheel et al. (1953) found that albumin delayed the rate of solution of quartz. Colloidal silica was not released in detectable amounts from aqueous or serum suspensions, even in the case of Aerosil. The passage of $\mathrm{COHb}$ through compact dust masses resting on membranes was delayed in the presence of undiluted serum and, under certain conditions, by the smaller Aerosil particles, whilst $\mathrm{COHb}$ solution failed to emerge from within used dust chambers in 24 hours. Moreover, undiluted serum retarded the escape of $\mathrm{COHb}$ from silica in solution. It is thus conceivable that dissolved silica may diffuse more slowly from the centre of dust masses in the presence of serum and smaller particles. The evidence does not suggest that membrane pores are obstructed by particles. The results of the two types of experiment used to test membrane permeability are not, however, comparable; escape of MR silica was measured from dust maintained in suspension, but for $\mathrm{COHb}$ diffusion studies the dust was tightly packed. The presence in vivo of a fibrous layer around the chambers may impede the solution of silica. It must be noted that within the period of the permeability studies free silica induced a vigorous reaction when in direct contact with the peritoneal tissues of rats.

Our biological findings with diffusion chambers resemble those of Pernis et al. (1958) and of Curran and Rowsell (1958), but, on the basis of the tests of membrane permeability, we interpret them differently. Pernis et al. and Curran and Rowsell considered that the tissue response to silica could not be attributed simply to the continuous application of low or high polymers of silicic acid; but the present results suggest that polymerized (colloidal) silicic acid, the form which is toxic and which may be fibrogenic, does not emerge from the chambers. Although the pores of the membranes we used were theoretically large enough to allow the passage of high polymers of silicic acid (e.g. Aerosil), silica particles enclosed in chambers evidently dissolved too slowly and the solution escaped too quickly to achieve the local external concentration necessary for polymerization. Unlike the previous workers, we do not therefore believe that this type of experiment can be used to decide the validity of the silica solubility theory of the pathogenesis of silicosis. To induce fibrosis closer contact is evidently needed between cells and silica than the membranes permit, but dissolved silica in high concentration and hence in a polymerized form may still be involved. This state may be achieved only after phagocytosis of silica particles, though the fact of ingestion, as observed by conventional means, 
does not suffice to distinguish between solution and a surface effect as the mechanism by which silica acts.

We are indebted to Dr. G. Nagelschmidt for providing the sized dust samples.

\section{REFERENCES}

Algire, G. H., Weaver, J. M., and Prehn, R. T. (1954). J. nat. Algire, Cancer Inst., 15, 493.

Banting, F. G. (1936), Canad. med. Ass. J., 35, 289.

Chvapil, M., and Holecková, E. (1959). Brit. J. industr. Med., 16, 286.

Curran, R. C., and Rowsell, E. V. (1958). J. Path. Bact., 76, 561.

Gardner, L. U.. (1934). J. Amer. med. Ass., 103, 743.

- (1937). In 3rd Saranac Laboratory Symposium on Silocosis, p. 75 .

Glömme, J., Holmquist, C-E., and Swensson, A. (1958). A.M.A. Arch. industr. Hlth, 17, 204.

Gye, W. E., and Kettle, E. H. (1922). Brit. J. exp. Path., 3, 241.

and Purdy, W. J. (1922). Ibid., 3, 75 and 86.

-, (1924). Ibid., 5, 238.

Holt, P. F., and Osborne, Sonia G. (1953). Brit. J. industr. Med., 10,152 .
-, and Went, C. W. (1960). Ibid., 17, 25.

Jäger, R. (1954). In Die Staublungenerkrankungen, Vol. 2, p. 142 Ed. Jötten, K. W., Klosterkötter, W., and Pfefferkorn, G. Steinkopff, Darmstadt.

James, Dinah M., and Marks, J. (1956). J. Hyg. (Lond.), 54, 342.

Kettle, E. H. (1926). J. industr. Hyg., 8, 491.

King, E. J., Stacy, B.D., Holt, P. F., Yates, Deidre M., and Pickles, D. (1955). Analyst, 80, 441 Zaidi, S. H., and Nagelschmidt, G. (1956). A.M.A. Arch industr. Hlth, 13, 133.

Knake, Else, Peter, H., and Müller-Ruchholtz, W. (1959). Beitr. Silikose-Forsch. No. 63, p. 35

Marks, J., and Nagelschmidt, G. (1959). A.M.A. Arch. industr. Hlth, 20, 383.

Paterson, M. S., and Wheatley, K. H. (1955). Safety in Mines Research Establishment, Ministry of Fuel and Power, Res. Rep. 124.

Pernis, Bep. Clerici, E., and Ghezzi, I. (1958). Med. d. Lavoro, 49, 672 Philbrick, F. A., Holmyard, E. J., and Palmer, W. G. (1949). A Text Book of Theoretical and Inorganic Chemistry, rev. ed., p. 278. Dent, London.

Scheel, L. D., Fleisher, E., and Klemperer, F. W. (1953). A.M.A. Arch. industr. Hyg. 8, 564.

Schepers, G. W. H. (1958). Proc. McIntyre Res. Foundation, 9, 1.

Seifert, H. (1954), In Die Staublungenerkrankungen, ed. Jötten, K. W., Klosterkötter, W., and Pfefferkorn, G. Vol. 2, p. 199. Steinkopff, Darmstadt. 